\title{
GENDER, DIET, AND METABOLIC SYNDROME IN ADOLESCENTS IN MALANG, EAST JAVA
}

\author{
Rizki Mustika Riswari1), Dono Indarto²) \\ 1) Polytechnic School of Health, Malang, Indonesia, \\ 2) Department of Physiology, Faculty of Medicine, \\ Sebelas Maret University, Surakarta
}

\begin{abstract}
BACKGROUND: Metabolic syndrome is a set of sympton causing degenerative disease. Metabolic syndrome is assesed based on individual body mass index, waist circumference, blood presure, triglyceride level, high density lipoprotein level, and fasting blood sugar level. People with overweight and obesity had an increased risk of metabolic syndrome. This study aimed to examine the relationship between gender, diet, and metabolic syndrome, in adolescents.

SUBJECT AND METHODS: This was a cross sectional study conducted in Malang, East Java. A sample of 227 adolescents was selected from several high school in Malang. The dependent variable was metabolic syndrome. The independent variables were gender and diet, which included energy, carbohydrate, protein, and fat intake. The data were analyzed using linear regression.

RESULT: There were positive and statistically significant relationships between metabolic syndrome and energy intake $(b=0.01 ; 95 \% \mathrm{CI}=0.009$ to $0.02 ; \mathrm{p}=0.026)$; carbohydrates intake $(\mathrm{b}=0.02,95 \% \mathrm{CI}=0.01$ to 0.04 ; $\mathrm{p}=0.012)$; protein intake $(\mathrm{b}=0.07 ; 95 \% \mathrm{CI}=0.03$ to $0.09 ; \mathrm{p}=0.010)$; fat intake $(b=0.06 ; 95 \% C I=0.04$ to $0.12 ; \mathrm{p}=0.002)$, gender $(b=1.81$; $95 \% \mathrm{CI}=0.08$ to $3.52 ; \mathrm{p}=0.039)$.
\end{abstract}

CONCLUSION: Diet and gender are risk factors for metabolic syndrome.

Keywords: metabolic syndrome, gender, diet 